\title{
Clinicomicrobiological spectrum of abnormal discharge from vagina in women in costal Andhra Pradesh
}

\author{
Jyothi Singamsetty, G. Sravani*
}

\begin{abstract}
Department of Obstetrics and Gynaecology, Konaseema Institute of Medical Science Amalapuram, Andhra Pradesh
\end{abstract} India

Received: 30 November 2020

Accepted: 17 December 2020

*Correspondence:

Dr. G. Sravani,

E-mail: gsravani@gmail.com

Copyright: (C) the author(s), publisher and licensee Medip Academy. This is an open-access article distributed under the terms of the Creative Commons Attribution Non-Commercial License, which permits unrestricted non-commercial use, distribution, and reproduction in any medium, provided the original work is properly cited.

\begin{abstract}
Background: When there is change in colour, consistency, order and volume of discharge then it is called abnormal vaginal discharge and associated with vulvar pruritus, dyspareunia, dysuria and lower abdominal pain. There is variability in organism isolated and treatment used.

Methods: Sexually active women in reproductive age group with complain of abnormal vaginal discharge were included in this study based in following inclusion and exclusion criteria. . A detailed history of patient was taken regarding nature of discharge, colour, smell along with dysuria, dyspareunia, itching of vulva and lower abdominal pain.

Results: Out of 160 patients 88 patients have bacterial vaginosis. Trichomonas vaginitis was present in $7.5 \%$ patients. Candidiasis was present in $6.25 \%$ patients. Some patients were having more than one infection like Bacterial vaginosis and Trichomonas vaginitis was coexisting in $13.75 \%$, Bacterial vaginosis + Candidiasis were present in $8.75 \%$ patients. Mixed infection was present in $8.75 \%$.

Conclusions: From present study we can conclude that vaginal discharge is more common in married women in young age. Patients commonly presented with curdy white discharge, pruritus vulva and lower abdominal pain. Erythema and excoriation in vulva were common presentation, followed by erythema of vagina. Nature of discharge was mucopurulent in most patients. Bacterial vaginosis was most common followed by Trichomonas vaginitis.
\end{abstract}

Keywords: Clinical presentation, Microbiology, Vaginal discharge

\section{INTRODUCTION}

Abnormal vaginal discharge is one of the most common gynaecological problems in reproductive age group. Normal secretion of vagina consists of a mixture of secretion from various glands, vaginal epithelial cells which are desquamated and transudate from mucous membrane. ${ }^{1}$ The nature of this secretion depends upon phase of menstruation cycle, hormonal status and oral contraceptive pills. When there is change in colour, consistency, order and volume of discharge then it is called abnormal vaginal discharge and associated with vulvar pruritus, dyspareunia, dysuria and lower abdominal pain. ${ }^{2,3}$ It is a cause of considerable discomfort to women and due to embarrassment the treatment used to delay. This condition occurs mainly due to imbalance between normal vaginal flora and abnormal organism. Candida species, Trichomonas vaginalis, Neisseria gonorrhoeae and Chlamydia trachomatis are the organism which is responsible for abnormal vaginal discharge. Ectocervix, endocervix and the vagina is the common site for infection. ${ }^{4,5}$ In addition to theses lactobacillus overgrowth syndrome is also responsible for abnormal vaginal discharge. ${ }^{6}$

Sivaranjini R, Jaisankar T, Thappa DM, et al has concluded in his study from south India that majority (26.25\%) have bacterial vaginosis and (12.5\%) were concurrently infected with trichomoniasis and $\mathrm{BV} .^{7}$ Gupta V, Gupta P, Chatterjee B, Bansal R et al has 
concluded that Bacterial vaginosis was the commonest aetiology $(43.6 \%)$, followed by candidiasis $(10 \%)$, trichomoniasis $(9.1 \%)$, senile vaginitis $(5.4 \%)$ and vaginitis of unknown origin $(5.4 \%) .{ }^{8}$ Patel V, Weiss HA, Mabey D, West B, D'Souza S, Patil V, et al has concluded that Endogenous infections were the most prevalent $(24.9 \%)$ and $\mathrm{BV}$ was the most common infection. ${ }^{9}$

The most common infection among 319 women was bacterial vaginosis $(26 \%)$ and the syndromic management of vaginal discharge among women seeking family planning and other reproductive health services should focus on vaginal infections. ${ }^{10}$

From literature survey it is clear that there is variability in organism isolated and treatment used.

Keeping these in view we have designed present study with an aim to know clinical presentation and microbiological spectrum of abnormal discharge from vagina in women in coastal Andhra Pradesh.

\section{METHODS}

\section{Place and time of study}

Present study has been conducted in the department of obstetrics and gynaecology Konaseema institute of medical science Amalapuram Andhra Pradesh India from January 2018 to September 2020.

\section{Type of study-}

This is a prospective observational study.

\section{Selection of patients}

Sexually active women in reproductive age group with complain of abnormal vaginal discharge were included in this study based in following inclusion and exclusion criteria.

\section{Inclusion criteria}

Age 18 to 45 years, Abnormal vaginal discharge as chief complain

\section{Exclusion criteria}

Bleeding per vagina, maliganancy, pregnancy, post partum, postmenopausal, Post-hysterectomy patients and use of antimicrobial agent

\section{Sample size}

Based on previous study sample size was calculated to be 160.

\section{Method}

As per selection criteria 160 patients with complain of abnormal vaginal discharge attending gynaecology outpatient department were included in the study. A detailed history of patient was taken regarding nature of discharge, colour, smell along with dysuria, dyspareunia, itching of vulva and lower abdominal pain. After that speculum examination was done to know the nature, colour and measure the PH. Sterile cotton wool vaginal swabs was used to take high vaginal swab by rubbing and rotating in the posterior vaginal fornix. One swab was taken for wet mount and second swab was sent for microbiology fro gram stain and culture. Bacterial vaginosis was diagnosed by gram stain, Trichomonas vaginalis was diagnosed by wet smear microscopy and Candidiasis was gram's stain. Syndromic-based management recommended by WHO was used for treatment.

\section{Statistical analysis}

Data were recorded in excel sheet and statistical Analysis was done with software SPSS-14 version. Data were calculated as percentage and proportions.

\section{RESULTS}

A total of 160 women with vaginal discharge were enrolled for this study as per exclusion and inclusion criteria. The mean age of women was $34.42+6.28$ years most of them were married (94\%) and belong to upper lower socio-economic group.

Table 1: Symptoms of patients presented with vaginal discharge.

\begin{tabular}{|llll|}
\hline Variables & & $\begin{array}{l}\text { Number } \\
(\mathbf{n = 1 6 0 )}\end{array}$ & Percentage \\
\hline Pruritus vulva & 82 & 50.61 \\
\hline \multirow{2}{*}{$\begin{array}{l}\text { Characteristic } \\
\text { of discharge }\end{array}$} & Curdy white & 98 & 61.25 \\
\cline { 2 - 4 } & frothy & 26 & 16.25 \\
\cline { 2 - 4 } & $\begin{array}{l}\text { Homogeneous } \\
\text { green }\end{array}$ & 28 & 17.5 \\
\hline Dysuria & 76 & 47.5 \\
\hline Dyspareunia & 43 & 26.87 \\
\hline Lower abdomen pain & 88 & 55 \\
\hline
\end{tabular}

Regarding symptoms of patients presented with vaginal discharge, $50.61 \%$ (82 patients out 160) patients were presented with pruritus vulva. Characteristic of discharge was different in different patients, Curdy discharge was present $61.25 \%$, frothy discharge was present $16.25 \%$ and homogeneous charge was present in $17.5 \%$. Dysuria was present in $47.5 \%$ patients. Dyspareunia was present in $27.87 \%$ patients and $55 \%$ patients were presented with lower abdominal pain.

Clinical finding was different in different patients. Regarding changes in vulva, $15 \%$ patients have 
excoriation and erythema was present in $10 \%$ patients. Cervical changes were present $7.5 \%$. Vaginal erythema were present in $10 \%$ patients. Regarding nature of discharge it was excessive in $30 \%$ patients, with malodour in $18.75 \%$ patients and purulent in $45 \%$ patients.

Table 2: Clinical finding in patients with vaginal discharge.

\begin{tabular}{|llll|}
\hline Variables & & $\begin{array}{l}\text { Number } \\
(\mathbf{n = 1 6 0})\end{array}$ & Percentage \\
\hline $\begin{array}{l}\text { Changes } \\
\text { in vulva }\end{array}$ & Excoriation & 24 & 15 \\
\cline { 2 - 4 } erythema & 16 & 10 \\
\hline Cervical changes & 12 & 7.5 \\
\hline Vaginal erythema & 16 & 10 \\
\hline \multirow{2}{*}{$\begin{array}{l}\text { Nature of } \\
\text { discharge }\end{array}$} & Excessive & 48 & 30 \\
\cline { 2 - 4 } & malodour & 30 & 18.75 \\
\cline { 2 - 4 } & purulent & 72 & 45 \\
\hline
\end{tabular}

Table 3: Microbiological spectrum of patients with vaginal discharge.

\begin{tabular}{|lll|}
\hline Variables & $\begin{array}{l}\text { Number } \\
(\mathbf{n = 1 6 0 )}\end{array}$ & Percentage \\
\hline Bacterial vaginosis & 88 & 55 \\
\hline Trichomonas vaginitis & 12 & 7.5 \\
\hline Candidiasis & 10 & 6.25 \\
\hline $\begin{array}{l}\text { Bacterial vaginosis + } \\
\text { Trichomonas vaginitis }\end{array}$ & 22 & 13.75 \\
\hline $\begin{array}{l}\text { Bacterial vaginosis + } \\
\text { Candidiasis }\end{array}$ & 14 & 8.75 \\
\hline Mixed & 14 & 8.75 \\
\hline
\end{tabular}

As per table 3, regarding microbiological spectrum of vaginal discharge out of 160 patients 88 patients have bacterial vaginosis. Trichomonas vaginitis was present in $7.5 \%$ patients. Candidiasis was present in $6.25 \%$ patients. Some patients were having more than one infection like Bacterial vaginosis and Trichomonas vaginitis was coexisting in $13.75 \%$, Bacterial vaginosis + Candidiasis were present in $8.75 \%$ patients. Mixed infection was present in $8.75 \%$.

\section{DISCUSSION}

In present study we have evaluated 160 patients with vaginal discharge, mean age of patients were $34.42 \pm 6.28$ years most of them were married $(94 \%)$ and belong to upper lower socio-economic group which is supported by the work of ) Sivaranjini R, Jaisankar T, Thappa DM, et al. ${ }^{7}$ In present study $50.6 \%$ patients were presented with pruritus vulva. Vijayalakshmi D, Patil Sunil S, Sambarey Pradip has reported that vaginal pruritus was most common presentation in his study and it was present in $36 \%$ patients which partially support our study. ${ }^{11}$ But our study is supported by Sharon L Hillier, Michele Austin et al. ${ }^{12}$ In present study regarding characteristic of discharge, Curdy discharge was present $61.25 \%$, frothy discharge was present $16.25 \%$ and homogeneous charge was present in $17.5 \%$. This is supported by the study of Venugopal S, Gopalan K, Devi A, Kavitha A et al. ${ }^{13}$

In our study lower abdominal pain was most common followed by dysuria and dyspareunia which corroborates with the study of Narayankhedkar A, Hodiwala A, Mane A et al and Saidu AD, Tunau KA, Panti AA, Nwobodo EI, Mohammed Y, Amin J, et al. ${ }^{14,15}$

Regarding clinical finding in patients changes in vulva was most common clinical finding followed by vaginal erythema and cervical changes. In most of the patient the discharge was purulent and in 305 patients it was profuse. This is supported by the work of Koumans EH, Sternberg $\mathrm{M}$ et al and Carr PL, Felsenstein D, Friedman RH et al. ${ }^{16,17}$

In our study bacteria vaginosis is most common followed by Trichomonas vaginitis and Candidiasis which is similar to the work of David A. Eschenbach, Sharon Hillier and Venugopal S, Gopalan K, Devi A, Kavitha A et al. ${ }^{13,18}$ Bacterial vaginosis and Trichomonas vaginitis was coexisting in $13.75 \%$, Bacterial vaginosis + Candidiasis were present in $8.75 \%$ patients. Mixed infection was present in $8.75 \%$ this finding is supported by the work of T. N. Gandhi, M. G. Patel, and M. R. Jain et al and P. Madhivanan, K. Krupp, V. Chandrasekaran et al. ${ }^{19,20}$

\section{CONCLUSION}

From present study we can conclude that vaginal discharge is more common in married women in young age. Patients commonly presented with curdy white discharge, pruritus vulva and lower abdominal pain. Erythema and excoriation in vulva were common presentation, followed by erythema of vagina. Nature of discharge was mucopurulent in most patients. Bacterial vaginosis was most common followed by Trichomonas vaginitis.

Funding: No funding sources Conflict of interest: None declared

Ethical approval: The study was approved by the Institutional Ethics Committee

\section{REFERENCES}

1. Glasier A, Metin Gulmezoglu A, Schmid GP, Garcia Moreno C, Van Look PFA. Sexual and reproductive health: a matter of life and death. Lancet 2006;368:1595-607.

2. Anderson MR, Klink K, Cohrssen A Evaluation of vaginal complaints. JAMA. 2004;291(11):1368-79.

3. Hainer BL, Gibson MV Vaginitis. Am Fam Physician. 2011;83(7):807-15.

4. Spence D, Melville C. Vaginal discharge. BMJ. 2007;335(7630):1147-51. 
5. Abdullah Yusuf Md, Chowdhury M, Shahidul Islam KM, Eva EO, Sharif AR, Khalilur Rahman Md, et al. Common microbial etiology of abnormal vaginal discharge among sexually active women in Dhaka, Bangladesh. South East Asia J Public Health. 2011;1:35-9.

6. Cerikcioglu N, Beksac MS. Cytolytic vaginosis: Misdiagnosed as candidal vaginitis. Infect Dis Obstet Gynecol. 2004;12:13-6.

7. Sivaranjini R, Jaisankar T, Thappa DM. Spectrum of vaginal discharge in a tertiary care setting. Trop Parasitol. 2013;3(2):135-9.

8. Gupta V, Gupta P, Chatterjee B, Bansal R. Clinicomicrobiological profile of women with vaginal discharge. J Indian Med Assoc. 2009;107(3):164-6.

9. Patel V, Weiss HA, Mabey D, West B, D'Souza S, Patil V, et al. The burden and determinants of reproductive tract infections in India: A population based study of women in Goa, India. Sex Transm Infect. 2006;82:243-9.

10. Vishwanath S, Talwar V, Prasad R, Coyaji K, Elias CJ, de Zoysa I. Syndromic management of vaginal discharge among women in a reproductive health clinic in India. Sex Transm Infect. 2000;76:303-6.

11. Vijayalakshmi D, Patil Sunil S, Sambarey PW. International Journal of Contemporary Medical Research Clinical And Microscopic Correlation of Vaginal Discharge ,International Journal of Contemporary Medical Research, Volume 3 | Issue 5 | May 2016 | ICV: 50.43 | ISSN (Online): 2393915X; (Print): 2454-7379

12. Sharon L Hillier, Michele Austin, Ingrid Macio, Leslie A Meyn, David Badway, Richard Beigi, Diagnosis and Treatment of Vaginal Discharge Syndromes in Community Practice Settings, Clinical Infectious Diseases, , ciaa260, https://doi.org/10.1093/cid/ciaa260

13. Venugopal S, Gopalan K, Devi A, Kavitha A. Epidemiology and clinico-investigative study of organisms causing vaginal discharge. Indian J Sex Transm Dis AIDS. 2017;38(1):69-75.

14. Narayankhedkar A, Hodiwala A, Mane A. Clinico etiological characterization of infectious vaginitis amongst women of reproductive age group from Navi Mumbai, India. J Sexually Trans Dis. 2015;1-5.

15. Saidu AD, Tunau KA, Panti AA, Nwobodo EI, Mohammed Y, Amin J, et al. Effect of hormonal and copper IUDs on genital microbial colonisation and clinical outcomes in North-Western Nigeria. Inter J Reprod Contracept Obstet Gynecol. 2017;6(6):2144.

16. Koumans EH, Sternberg M, Bruce C, McQuillan G, Kendrick J, Sutton M, Markowitz LE. The prevalence of bacterial vaginosis in the United States, 2001-2004; associations with symptoms, sexual behaviors, and reproductive health. External. Sex Transm Dis. 2007;34(11):864-9.

17. Carr PL, Felsenstein D, Friedman RH. Evaluation and management of vaginitis. J Gen Intern Med. 1998;13(5):335-46.

18. David A. Eschenbach, Sharon H, Critchlow C, Stevens C, DeRouen T, Holmes KK. Diagnosis and clinical manifestations of bacterial vaginosis, American J Obstetrics and Gynecol. 1988;158(4): 819-28.

19. Gandhi TN, Patel MG, Jain MR. "Prospective study of vaginal discharge and prevalence of Vulvovaginal candidiasis in a tertiary care hospital," International J Current Research and Review. 2015;7(1):34-8.

20. Madhivanan P, Krupp K, Chandrasekaran V. "Prevalence and correlates of bacterial vaginosis among young women of reproductive age in Mysore, India," Indian J MedicMicrobiol. 2008;26(2):132-7.

Cite this article as: Singamsetty J, Sravani G. Clinicomicrobiological spectrum of abnormal discharge from vagina in women in costal Andhra Pradesh. Int J Reprod Contracept Obstet Gynecol 2021;10:150-3. 